\title{
NARCISO: POLIMORFISMO DAS VERSÕES E DAS INTERPRETAÇÕES PSICANALÍTICAS DO MITO
}

\section{NARCISUS: POLYMORPHISM OF VERSIONS AND ITS PSYCHOANALITICAL INTERPRETATIONS}

\author{
Paulo de Tarso UBINHA ${ }^{1}$ \\ Roosevelt Moíses Smeke CASSORLA²
}

\begin{abstract}
RESUMO
Apresentamos neste trabalho diferentes versões do mito de Narciso, cada qual com diversificadas variações de detalhes, implicando diferentes possibilidades de interpretações psicanalíticas. Este polimorfismo das formas de relato do mito e de suas múltiplas compreensões parece refletir a própria indiferenciação dos estágios iniciais do desenvolvimento da mente humana e da complexidade que seu estudo oferece. Trata-se de uma questão em aberto e que assim deixamos permanecer, para favorecer novas reflexões para fazer progredir o estudo deste conceito básico, mas controvertido, da teoria psicanalítica.
\end{abstract}

Palavras-chave: mitologia, versões do mito de Narciso, narcisismo, mito e psicanálise.

\begin{abstract}
In this paper are presented different versions of the myth of Narcisus, everyone of which with variations in details, what leads us to different possibilities of psychoanalytic interpretations. This polymorphism in the various forms of reports and of its multiple comprehensions seems to reflect the indifferentiation of the initial stages of mind development and the complexity its study offers to. The question remains overt and so we wish it does, in order to make progressing the study of this so basic and controversial concept in the psychoanalytic theory.
\end{abstract}

Key words: mythology; versions of Narcisus myth; narcissism; myth and psychoanalysis.

\footnotetext{
(1) Psicanalista, membro associado da Sociedade Brasileira de Psicanálise de São Paulo - Endeereço para correspondência: R: Engenheiro Carlos Stevenson, 508 - Nova Campinas - Campinas/SP Cep: 13092-310 - E-mail: peteu01@terra.com.br (2) Doutor e Professor Titular pela Faculdade de Ciências Médicas da UNICAMP, Analista didata da SBP/SP.
} 


\section{INTRODUÇÃO}

Desejamos inicialmente assinalar que, neste trabalho, nos cingiremos a tecer breves considerações críticas para a análise do mito de Narciso, ressaltando os aspectos que interessam diretamente à abordagem psicanalítica, sem nos estendermos em questões de interesse específico para um estudo mais abrangente da mitologia.

Assim, deixaremos de lado a questão técnica, da esfera dos mitólogos, sobre ser a estória de Narciso um mito ou uma lenda. Como nosso interesse é de ordem psicológica e, mais especificamente, de ordem psicanalítica, nós a consideraremos como mito, amparados no emprego usual pelos psicanalistas da expressão "mito pessoal" e da descrição, em psicanálise, de um tipo especial de atividade mental, a que se dá o nome de pensamento mítico ou onírico (Bion,1966).

Azoubel Neto (1993) exime-nos de nos estendermos em considerações sobre a utilidade do conceito de mito para a prática da psicanálise, porque já o faz competentemente em seu livro "Mito e psicanálise", mas não nos dispensamos de extrair de seu texto esta citação:

"A psicanálise redescobriu o mito, retomou o seu estudo e fê-lo através de um método de trabalho próprio, um método que constitui em si um processo de resgate. Localizou a presença do mito como uma condição real, atuante e atual no inconsciente" (p.15).

Aponta em seguida, com agudeza, que Freud concebia o inconsciente não apenas como um depósito do reprimido, mas também como um sistema dinâmico e criativo, repositório do acervo histórico e pré-histórico da mente humana.

\section{AS VERSÕES DO MITO DE NARCISO}

Há quatro registros literários do mito de Narciso e, em torno desses, muitas variações. Os mais antigos são de Ovídio e Cânon, no século I, seguindo-se dois mais recentes, de Pausânias, no século II.

\section{1 - O MITO DE NARCISO SEGUNDO OVÍDIO}

Ovídio, em seu belo poema Metamorfoses, nos dá a versão mais conhecida e mais extensa, falando-nos da desventurada relação entre Eco e $\mathrm{Narciso}^{3}$, que resumiremos.

A ninfa Liríope, violada pelo deus-rio Céfiso, "que a abraçou em sua correnteza coleante ...enquanto a mantinha aprisionada em suas águas", veio a dar à luz um menino de raríssima beleza, a quem deu o nome de Narciso. Perturbada pela estonteante formosura do filho, foi consultar o adivinho Tirésias, famoso por todas as cidades da Beócia, o qual, indagado se esta criança viveria muito, replicou: "Se ele jamais se conhecer".

"Por muito tempo, as palavras do adivinho pareciam sem sentido. Maso que sobreveio mostrou-lhes o acerto - o incidente, o modo como o rapaz morreu, a estranheza de sua louca paixão".

Aos dezesseis anos Narciso já era assediado por muitos jovens e donzelas, que procuravam o seu amor, "mas, naquela esbelta forma, era tão frio e orgulhoso, que não houve jovem ou donzela que Ihe tocasse o coração".

Certa vez, caçando um veado assustado, foi "seguido por uma ninfa, de estranha voz, a retumbante Eco, que não podia ficar em paz quando os outros falavam, nem começar a falar enquanto alguém não Ihe dirigisse a palavra".

(3) Servimo-nos da tradução para o português (de Adail Ubirajara Sobral e Maria Stela Gonçalves) da versão para o inglês do texto latino, por Louise Vinge, in Scwartz-Salant (1982),p.97-101, e de outros textos mais concisos (Urtubey, Canevacci e da Internet, referidos na bibliografia). 
Eco, de fato, só podia repetir a fala alheia, devido a um castigo que Ihe aplicou Juno (Hera), porque, em tempos idos, ela ficava a tagarelar, desviando a atenção da deusa, que assim não conseguia surpreender seu esposo Júpiter (Zeus) em companhia das ninfas nas encostas das montanhas.

Enamorada, Eco desejava transmitir ao seu amado tudo o que sentia, mas não podia fazê-lo, por força do castigo sofrido.

Quando Narciso, percebendo sua presença, indagou: "Há alguém aqui?", apenas ecoou: "Aqui!" E o que se seguiu, foi o único diálogo possível:

- "Aproxima-te!" - exclama o jovem

- "Aproxima-te!" - repete o eco.

Olhando para trás de si e em torno, surpreso, sem ver ninguém se aproximando, indaga:

- "Porque foges de mim?".

- ".foges de mim" - ressoa Eco.

- "Aqui nos encontraremos!"

- "...nos encontraremos!" - reverbera, entusiasmada e, crendo ser desejada, sai da vegetação e corre a enlaçar-se no pescoço do mancebo. Este, porém, foge dela, dizendo:

- "Retira as mãos de mim, não me abraces! Que eu morra antes de conceder-te poder sobre mim"

- "Conceder-te poder sobre mim" - reitera e se cala.

Rejeitada, recolhe-se entristecidaà floresta, passa a viver nas cavernas vazias, não come, nem dorme, definha, enruga-se e descarna-se, até que todo o viço do seu corpo se desfaz no ar, só lhe restando a voz e os ossos, e depois nem esses mais, pois dizem que se transformaram em pedra. E agora "esconde-se nas florestase já não é vista nas encostas das montanhas; mas todos a podem ouvir, pois a voz, e somente a voz, ainda vivem nela".
Continuando a desprezar moças e rapazes, desdenhou as ninfas das ondas e das montanhas, até que uma das jovens desdenhadas bradou aos céus: "Pois que possa ele amar a si mesmo e não obter aquilo que ama!".

A deusa Nêmesis ouviu sua justa prédica.

Havia uma clara fonte de águas límpidas e prateadas, à qual nenhum pastor ou animal havia jamais chegado, cuja superfície perfeita nunca fora maculada por ave, besta, sequer um galho caído. Atraído pela paisagem e pela fonte, Narciso ali se debruça e enamora-se perdidamente da bela forma que vê e, num estado de deslumbramento, ali permanece imobilizado, como uma estátua de mármore ou tenta alcançar aquele quevê.

"Ó, jovem, apaixonadamente tolo, porque buscas, debalde, abraçar uma imagem fluida?" - diz uma voz desconhecida, não se sabe de onde vinda.

À margem do lago, Narciso definha, sem comer, sem dormir, sem descanso, tolamente iludido com a correspondência do amor da imagem e, sem reconhecê-la como o próprio reflexo, pensa que estende os braços em direção a um ser e não a uma sombra, e que aproxima os lábios aos dela, sempre que se inclina para beijar a bela figura suposta, que o arrebata. Ao chorar por não poder capturar o amado em seus braços, suas lágrimas turvam o lago e fazem desaparecer a imagem na água perturbada. Desespera-se ante a ameaça de perder seu amor, golpeia-se, vai-se consumindo até a morte.

Suas irmãs náiades o vêm buscar com o ataúde e as tochas nas mãos para conduzi-lo à pira funerária, mas, em lugar de seu corpo, encontram uma flor, cujo centro amarelo estava cercado de pétalas brancas.

Ainda quando sua sombra atravessa o Estige, debruça-se sobre o barco para avistar-se nas águas. 


\section{2 - O MITO DE NARCISO SEGUNDO CANON ${ }^{4}$}

Em Tépsias (ou Tépis), na Beócia, cidade próxima ao monte Helicon, vivia o jovem Narciso, muito belo, mas orgulhoso, desprezando a Eros e a todos os que o amavam. Seus apaixonados dele desistiam, mas Ameínias persistia em seus apelos. Porém, Narciso não o recebeu e enviou-lhe uma espada, com a qual cometeu suicídio à porta de Narciso, não sem antes rogar aos deuses vingança.

Quando viu sua própria figura numa fonte, Narciso tornou-se de forma estranha absurdamente enamorado de si mesmo. Confuso e convencido de que sofria tão somente em razão do desdém com que acolhera o amor de Ameínias, ele terminou por suicidar-se com a espada devolvida.

Depois disso, os tespieses decidiram temer e honrar mais a Eros nas cerimônias públicas, assim como fazer sacrifícios em seu louvor nos serviços privados.

Acreditam os habitantes da área que a flor narciso tenha despontado pela primeira vez no solo em que se verteu o sangue do belo e infortunado jovem.

\section{3 - O MITO DE NARCISO SEGUNDO PAUSÂNIAS 5}

Pausânias apresenta um relato curto e, a seguir, uma narrativa mais longa da estória de Narciso, esta última com um enredo totalmente diverso dos anteriores.

A primeira menção é quase um breve informativo, que nos dá conta de que, na terra dos tespieses, existe um local chamado Donakon (Canteiro de juncos), onde se encontra a fonte de Narkissos, em que, segundo se conta, um jovem, olhando para dentro d'água e sem perceber que estava vendo sua própria imagem, enamorou-se de si mesmo. Como conseqüência desse amor, sobreveio a morte junto à fonte.

Considera Pausânias esta fábula, assim contada, perfeitamente idiota, pois parece uma tolice que um indivíduo, com idade para enamorar-se, não seja capaz ao menos de distinguir o que seja um homem e o que seja a imagem de um homem.

A seguir, admitindo que a versão que se seguirá é menos conhecida, conta que Narciso tinha uma irmã gêmea muito parecida com ele, vestiam-se da mesma maneira e penteavam os cabelos do mesmo modo, além de irem à caça em companhia um do outro.

Narciso enamorou-se da irmã, que veio a morrer. la ele à fonte, após a morte dela, para contemplar sua imagem e, embora soubesse que via seu próprio reflexo, obtinha consolo no seu amor, ao imaginar que via, não sua própria imagem, mas a aparência de sua irmã.

Quanto à origem da flor narciso, na opinião de Pausânias, parece-lhe anterior a Narciso, o téspio, a crer nos versos do poeta Pamphos, segundo o qual a Donzela (Perséfone), filha de Demeter (Ceres), foi raptada quando colhia narcisos, num período anterior ao da história desse jovem.

\section{IMPLICAÇÕES PSICANALÍTICAS DO MITO DE NARCISO}

Canevacci observa que, nestes quatro relatos, podemos distinguir, conforme as relações entre Ego e Alter, quatro modalidades: autoerótica (Pausânias I), andrógina (Pausânias II), homossexual (Canon) e heterossexual (Ovídio).

Em cada versão, Ego é constante e Alter varia:

- na versão auto-erótica alter é igual a ego e do mesmo sexo

(4) Schwartz-Salant (nota 107,p.235); Canevacci (p.94, onde se grafa Conon,narr.24).

(5) Schwatrz-Salant (p.191/2); Urtubey (p.150); Canevacci (p.94). 
- na versão andrógina, alter é igual a ego, mas de outro sexo

- na versão homossexual, alter é diferente de ego, mas do mesmo sexo

- na versão heterossexual, alter é diferente de ego e de outro sexo.

Detalharemos em seguida alguns elementos integrantes do mito, para proceder a um estudo analítico.

Relações interpessoais - nas diferentes versões apresentadas caracterizamos dois tipos de relações: unitária e dual.

a) na relação unitária, só aparece um personagem, Narciso, que se relaciona consigo mesmo., na versão denominada auto-erótica. $\mathrm{O}$ investimento total em si mesmo, com retraimento dos demais e de todo interesse pelo mundo externo define o autismo, tanto entendido como uma patologia, que se engloba nas formas de psicoses infantis, quanto como um dos sintomas fundamentais da esquizofrenia, um aspecto que foi estabelecido por Bleuler. Freud iria considerar que a fase auto-erótica era o ponto de fixação da esquizofrenia, que nisto se diferenciaria da paranóia, cujo ponto de fixação estaria na fase do narcisismo (ESB, Vol.XII, 102).

$\mathrm{Na}$ lição 26 de suas Conferências Introdutórias, Freud deixa claro que "o auto-erotismo é a atividade sexual do estado narcisístico da libido" (E.S.B.,XVI: 486), deixando de demarcar uma fronteira entre duas fases diversas, como fizera em Sobre o Narcisismo (E.S.B.,XIV:93), em que o narcisismo seguia o auto-erotismo.

b) nas formulações duais do mito, observamse dois tipos de movimentos em relação ao objeto amoroso, de afastamento ou de aproximação. O afastamento se dá na fuga de Eco e na recusa ao amor de Ameínias, nas versões heterossexual e homossexual. A recusa de Narciso ao amor homoerótico de um jovem apaixonado parece pôr em xeque a formulação do homossexualismo a partir do narcisismo, pois Narciso desconhece outro amor que não seja direcionado à sua própria pessoa. No entanto, a explicação de Freud sobre a importância do narcisismo na gênese do homossexualismo é mais complexa, envolvendo um processo de identificação do menino com a mãe, justamente chamado identificação narcísica, que o faz amar a outros rapazes como foi amado pela mãe; isso deixou assente em sua análise de Leonardo da Vinci (E.S.B., XI).

A relação dual de aproximação requer um elucidamento mais detalhado. Na relação de Narciso com sua irmã gêmea, idêntica a ele, de tal forma que mal se distingue um do outro, estamos diante de um tipo de relação fusional, mais parecida com uma forma unitária do que propriamente diádica.Também podemos especular que a irmã de Narciso, dadas as suas características, representa a parte feminina dele mesmo, uma maneira de o mito representar a bissexualidade constitucional do ser humano, segundo Freud. Portanto, só aparentemente seria dual, mas no fundo, teríamos uma espécie de relação unitária.

Ainda vale notar que, nesta relação dual em tela, é Narciso quem ama sua irmã, ao contrário das anteriores, em que ele é amado e recusa o amor a ele dirigido, seja pela ninfa, seja pelo rapaz. Contudo, se, como vimos, a relação é fusional ou, de fato, não passa de uma espécie de unidade escamoteada, o que temos, afinal, é um enamoramento de si mesmo disfarçado.

Finalmente, o fato de existir uma irmã gêmea idêntica coloca a questão do duplo, abordada por Freud em "O Estranho", em que são discutidos aspectos do sujeito colocados noutras pessoas. Esse tema liga-se à especularidade, fenômeno pelo qual o indivíduo indiferenciado sente-se espelhado no outro. A propósito, Kohut descreve um tipo de transferência narcisística, precisamente chamada gemelar, em que o analista é visto como se fosse uma alma gêmea do paciente.

A qualificação de andrógina, dada por Canevacci para a segunda narrativa de Pausânias, não nos parece justificável, pois androginia refere-se mais a uma aparência feminil de um rapaz ou uma discreta masculinização de 
uma moça, sem chegar à rusticidade de uma virago e não implica necessariamente outras conseqüências, tais como a prática do homossexualismo ou sequer um enamoramento platônico. Como parece referir-se a um aspecto feminino inerente às pessoas, melhor caberia o qualificativo bissexual para caracterizá-la, o que parece mais condizente com a idéia de Freud da bissexualidade constitucional do ser humano.

A concepção do homem constituído de um lado feminino e outro masculino encontra apoio no mito de Hermafrodito, o filho bissexual do deus mensageiro Hermes e da deusa do amor Afrodite. A ninfa Salmacis, de Halicarnasso, vendo-se não correspondida por esse belo jovem, pediu aos deuses que a unissem eternamente a ele. Do atendimento ao seu pedido resultou um rapaz feminino, mas que conservou seus genitais, donde deriva o termo hermafrodita. No hermafroditismo estão presentes as duas genitálias, ainda que uma possa estar atrofiada.

Próximo desta linha, Schwartz-Salant sugere que Perséfone, cujo mito articula com o de Narciso, representa um lado feminino oculto e dividido do caráter narcisista. Talvez, pensamos nós, corresponda a certos tipos de personalidades ou a certo aspecto delicado e suscetível de uma pessoa, que pode ser aproximado, se atinge grau de extrema suscetibilidade e vulnerabilidade, ao narcisista de pele fina, de que nos fala Herbert Rosenfeld, em contraste com o de pele grossa, comparável ao narciso venenoso ${ }^{6}$.

Filiação - na maioria das versões do mito, Narciso é filho de uma ninfa aquática, Alciope ou Leriope com o rio Cefiso, vindo, pois, do elemento água, ao qual se liga mar, e do latim mare provém Maria, figura materna por excelência, mãe de Deus, na doutrina cristã. Apontamos essas referências para salientar a ligação de Narciso ao elemento natural, que contém um bojo de associações com a figura materna, salientando o aspecto dual, o bebê e sua mãe, numa relação especial de fusão, indistinção inicial entre o sujeito e seu objeto de amor e de apoio, que caracteriza o narcisismo primário.

Faremos aqui uma breve digressão teórica, pois o conceito de narcisismo primário sofre transformações em Freud, ao longo de sua obra, o que nos obriga a tecer algumas considerações elucidativas.

O narcisismo primário implica admitir um estágio do desenvolvimento em que o ego é investido e Freud, em "Sobre o Narcisismo", situa-o em seguida ao auto-erotismo, argumentando que o ego não existe originalmente como uma unidade, sendo necessária "uma nova ação psíquica" para provocar o narcisismo. Freud não explicita em que consiste essa nova ação psíquica, mas fica claro que o ego tem de ser constituído e isto se faz nesta fase, o que favorece a visão de Lacan (1949) em considerar o narcisismo estruturante na constituição do sujeito.

Em Conferências Introdutórias, na que trata da teoria da libido e o narcisismo, este aparece como estado original, a partir do qual o amor objetal se desenvolve "sem que o narcisismo desapareça necessariamente” (E.S.B.,XVI: 485).

Em "Psicologia das massas e análise do ego" (1921), Freud radicaliza a teoria do narcisismo primário: "Ao nascer, dá-se o primeiro passo desde um narcisismo absolutamente auto-suficiente à percepção de um mundo externo cambiante e ao início do descobrimento dos objetos". (ESB,XVIII:164).

Já em "O ego e o id" (1923), com o estabelecimento da nova teoria estrutural, vamos encontrar uma concepção inusual do narcisismo secundário, que não reencontramos em outra parte e assim se coloca: "Bem no início, toda a libido está acumulada no id, enquanto que o ego ainda se acha em processo de formação ou ainda é fraco. O id envia parte dessa libido para catexias objetais eróticas; em conseqüência, o ego, agora tornado forte, tenta apoderar-se dessa

\footnotetext{
(6) ver adiante o tópico "A flor".
} 
libido do objeto e impor-se ao id como objeto amoroso. O narcisismo do ego é, assim, um narcisismo secundário, que foi retirado dos objetos." (E.S.B.,XIX: 62).

Encerrando essa digressão, que pretendíamos breve e já se alonga, consideraremos como uma declaração final mais satisfatória a seguinte asserção, feita na obra póstuma, "Esboço de Psicanálise".

"Podemos imaginar um estado inicial como sendo o estado em que a energia total disponível de Eros, a qual, doravante, mencionaremos como libido, acha-se presente no ego/id indiferenciado" (E.S.B.,XXIII: 175).

Concepção - a forma como se deu a concepção de Narciso é descrita por Ovídio como um estupro, de que resultou, segundo Quilici, uma gravidez penosa e indesejada. O pano de fundo violento em que se dá a concepção e gestação de Narciso indica a aversão às ligações amorosas, também ressaltada na atitude de Narciso diante de Eco: "Retira as mãos, não me abraces, afasta-te!"., a mesma diante de Ameínias e muitos outros e outras.

Noutra versão, na qual ainda se evidencia a aversão ao vínculo amoroso, é Liríope quem rejeita Eros, ao ser perseguida por ele. Sendo este deus muito vingativo com as pessoas que o desprezassem, flechou a ninfa quando ela se banhava nas águas do rio Cefiso, fazendo-a tomar-se de paixão pela divindidade das águas e não atender aos apelos de Afrodite, que, não sendo atendida, enfurecida, deixou-a à sua própriasorte. ${ }^{5}$ Embora nesta variação não fique evidenciada a violação, no entanto a forma de concepção é igualmente arrebatada e impulsiva, sem plena consciência da ação, ficando comprometida a livre deliberação da vontade.

Narciso não foi concebido de forma consciente, como fruto desejado numa relação assumida voluntariamente de um desejo plenamente desenvolvido. Todas as relações afetivas descritas são claramente imaturas.

Eros, água, rio Cefiso, ninfa Leriope, Narciso - toda essa rede associativa remete a formas primitivas de amor, da qual Afrodite é também representante, sendo "uma divindade arcaica da feminilidade”, a verdadeira fêmea, que está além de qualquer moralidade, pois é do tempo anterior ao aparecimento da moral, sendo vaidosa, ciumenta, irada, vingativa (Johnson,1921). Crono cortou o pênis de Urano e o jogou ao mar, dele nascendo Afrodite, também conhecida como Urânia. O vocábulo uranismo significa inversão sexual, homossexualismo masculino, o que remete a uma das versões do mito de Narciso.

Um registro do mito estabelece que Afrodite era afrontada por Narciso, que se gabava de ser imune às flechas de seu filho Eros (Cupido) e, quando Eco foi por ele humilhada, Afrodite indignou-se e instruiu seu filho a atirar a seta em Narciso, quando este se inclinasse diante da fonte $^{8}$. Uma variação deste relato diz que Eros deu à Ártemis (Diana), deusa da caça, - de quem Eco era favorita e a quem se queixaram as ninfas das montanhas pela atitude de Narciso - a seta que atingiu o belo jovem.

A profecia - no poema ovidiano aparece com destaque a figura do adivinho Tirésias, que vaticina o destino de Narciso, já no início da narrativa do episódio e vai reaparecer no seu fechamento, quando proclama o poeta das Metamorfoses:

"Quando essa história foi contada além, aumentou a bem merecida fama do vidente por todas as cidades da Grécia e grande era o nome de Tirésias."

Notando que Tirésias surge como elemento comum nos mitos de Narciso e Ėdipo, Zimerman (2001) conclui agudamente que a indiscriminação é incompatível com a diferen-

\footnotetext{
(7) www.grupo (Internet).

(8) Menelaos Stephanides.

(9) Schwartz-Salant,101.
} 
ciação, pois o vir a conhecer-se, que, no vaticínio revelado a Liríope, provocaria a morte de Narciso, implica o reconhecimento da diferença do outro, o que já nos introduz no terreno de Édipo, pela superação do narcisismo, faz-se a transição do espelho da ilusão para o mundo da realidade. O mundo de Narciso é o da indiferenciação pré-edípica.

A profecia feita por Tirésias comporta duas variantes. Na primeira, Narciso viverá muito sem jamais se conhecer; noutra, perecerá se vier a mirar-se.Uma enfatiza os perigos do autoconhecimento, outra a visão apaixonada de si, o desprezo pelo amor de outrem.

O espelho - Narciso mira-se no espelho das águas, estabelecendo o aspecto visual do mito, que nos remete à relação exibicionismo-voyeurismo com uma manifestação erótica particular, ligada à esfera do narcisismo. A luz, referida no mito de Narciso, transparece como elemento de compreensão tanto da cegueira, que o encerramento em si mesmo traz, quanto do esclarecimento que se segue, ao ser vencido um preconceito científico.

A luz do autoconhecimento se produz no "insight" psicanalítico, visão interna, que liberta e exige o abandono de cegueiras narcísicas obstrutoras.

Bion (2000), especialmente, desenvolveu as implicações epistemológicas que se podem aduzir do mito, estudando a obstrução da onipotência do pensamento ao pleno conhecimento, impedindo a iluminação, obstaculizada pela aderência ao senso comum. O advento de novas idéias torna-se capaz de trazer clareza de compreensão, quando o progresso do pensamento encontra obscuridades tamanhas, que exigem a derrocada do sistema ideológico vigente e o estabelecimento de uma nova ordem de conceitos e ações. Isso se dá no campo da política, da ciência e da religião, como nos atesta a história.
Podemos entender o dogmatismo religioso, político e científico a partir de um espelhamento narcisista recíproco entre os vários membros de uma coletividade, criando uma espécie de narcisismo fundamentalista, avesso ao surgimento do novo e do diverso.

Outrossim, lembramo-nos do famoso "sinal do espelho" das aulas de semiologia psiquiátrica, citado pelos professores de psicopatologia como um sinal característico da esquizofrenia e dado como fato universalmente conhecido, dispensando referência específica a qualquer autor, e que aparece em vários filmes de cinema, em que o psicótico é posto a se olhar demoradamente diante de um espelho, às vezes fitando fixamente a própria imagem, às vezes vendo-a distorcida de forma monstruosa e assustadora, noutras ocasiões levando o doente a espatifar a superfície refletora de sua auto-imagem com um murro, numa reação de fúria persecutória.

Metaforicamente, fala-se no espelhamento do olhar materno, de admiração desta por seu bebê e de extasiamento deste por ela, num tipo de vínculo fusional, que muitas vezes não se supera e trará conseqüências tardias no desenvolvimento amoroso do novo ser ou contribuirá para a manutenção de vínculos patológicos, dada a sua inadequação à intensidade e à extemporaneidade.

Kohut, um pesquisador especializado no tema do narcisismo, com contribuições originais, descreve, entre as formas de transferências narcisísticas, as especulares, que ficam subdivididas em dois subtipos, conforme o modo como pacientes muito regredidos se ligam ao analista: o fusional, em que o analisando vê o analista como mera extensão sua, capaz de lhe adivinhar os pensamentos, comungar os mesmos valores e ideais; e o especular, propriamente dito, que corresponde à demanda do paciente para que o analista reconheça e espelhe o seu self grandioso. ${ }^{10}$

A flor - que nasce onde Narciso morreu - é um símbolo de ressurreição, mas ao

(10) Kohut, IN: Zimerman, Voc.Cont.de Psicanálise, p. 414. 
mesmo tempo pode ser entendida como uma forma de reparação mágica ou, como dirá Melanie Klein, maníaca, com base em mecanismos de onipotência e culpa paranóide.

Narkissos, nome da flor e do mancebo, vem de narké, entorpecimento, raiz etimológica de narcótico. Num estado de obnubilação dos sentidos, Liríope deixa-se envolver nas águas volutas do rio Cefiso, estado de mente alterado que é reforçado na narração em que Eros a flecha nas margens do rio, tornando-a intensamente enamorada, como se estivesse sob influência de alguma poção mágica. Aliás, Liríope deriva de leyrion, a flor lírio, de que algumas espécies têm poder psicomimético, como bem o sabem os cultores de algumas seitas que utilizam o chá de lírio com finalidades rituais.

A reparação maníaca (Hinshelwood,1992), enquanto manifestação do pensamento mágico e do sentimento de onipotência, tem bases frágeis e tenderá a falhar, como dá conta o castigo eterno imposto a Narciso, numa das variações do mito, prolongando-se seu sofrimento no Hades. Podemos ver aqui representada a atuação de um superego cruel, contrapartida à reparação maníaca, mostrando que, quanto mais primitiva a defesa, mais primitiva a reação contra ela. No universo mitológico tudo é intenso: os desafios e as façanhas que dão conta deles, as estupendas estratégias para vencer armadilhas e decifrar enigmas, as punições severas impostas aos heróis pela cólera dos deuses.

A descrição da flor que surge no local onde morreu Narciso varia entre os autores: ora tem um centro amarelo, cercado de pétalas brancas $^{11}$, ora é roxa, rodeada de folhas brancas ${ }^{12}$, ora é um narciso branco de corola vermelha, do qual se extrai um bálsamo com efeitos narcóticos ${ }^{13}$.
Num texto de botânica, informa-se que este é um gênero em que se apresentam muitas dificuldades na identificação e taxonomia das diferentes espécies, pois é cultivado há longos anos e existe hibridação e seleção em larga escala, havendo uma subseqüente fuga de plantas e conseqüente naturalização. Nele, se incluem flores solitárias ou em umbelas de 2-15 flores, amarelas, brancas ou bicolores (raramente verdes), algumas vezes perfumadas ${ }^{14}$. No hino homérico dedicado a Demeter, é descrito um narciso de aparência mágica:

"Era ele objeto de admiração para todos, para os deuses imortais, como para os homens mortais. E de suas raízes nasceram mil cabeças, que exalavam um olor tão suave que todo o amplo céu acima, toda a terra e todas as salgadas ondas do mar sorriam." 15

Crime e castigo - de que vício ou crime fala este mito, que justifique o castigo e que tipo de reação moral se produz?

Quando Liríope assusta-se diante da formosura incomparável de seu filho, aparece em cena o grande vício da hybris, ultrapassagem do métron, a transgressão da harmonia e da medida, tão exaltadas pelos gregos. E a ação viciosa prossegue na vaidade e no orgulho de Narciso, no desmedido amor a si mesmo.

O castigo não é a morte, propriamente, mas a condenação ao amor impossível pela sua própria imagem inalcançável, que prossegue depois da morte, fazendo-o contemplar-se no Estige, rio da morte. Esta pena se perpetua pelo tempo afora, como se depreende de o jovem Orfeu, muito mais tarde, tê-lo encontrado pranteando o silêncio de seu amado.

(11) Ovídio, apud Schwartz-Salant.

(12) geocities.yahoo (Internet).

(13) www.grupo (Internet).

(14) www.uevora.pt (Internet).

(15) Schwartz-Salant, p.193. 
"Nem mesmo a poesia divina de Orfeu acalentaria a dor de Narciso"16.

A emotividade predomina nos domínios de Narciso e o pensamento é mágico, características de um universo primitivo, comparável aos primórdios da humanidade e do desenvolvimento infantil. Com razão, Melanie Klein (1946) o situa na fenomenologia da posição esquizoparanóide, pois não há em Narciso a dimensão da culpa e do remorso pela dor causada a outrem, só atingíveis na posição depressiva.

Mesmo na versão de Cânon, o suicídio de Narciso parece mais um desespero diante da impossibilidade de alcançar a figura amada espelhada na água do que um justo arrependimento diante da morte suicida de Ameínias pela espada que a ele ofertara. Sua consciência não passou da presunção de que estava sofrendo um castigo dos deuses, sem atingir um nível genuinamente ético, de autoconsciência moral. Se há traço de culpa, é da natureza da culpa persecutória (Grinberg,1978), que melhor se chamaria temor ao castigo.

Fiel ao espírito primitivo, o castigo é implacável, seguindo a lei de talião: se desprezou os amantes, será desprezado pelo amado; se provocou o suicídio, morrerá também pelas próprias mãos. A sentença, como se ditada por um superego arcaico cruel, é cumprida mesmo após a morte, como condenação perpétua no reino de Hades.

Quem aplica a pena é Nêmesis, a deusa da vingança, forma primitiva de justiça, ao estilo das Fúrias ou Erínias, que dominaram as aplicações das penas, de forma cruel e inclemente, nas tragédias gregas anteriores ao julgamento de Orestes pela morte de sua mãe Clitemnestra, responsável, em acumpliciamento com Egisto, pela morte de seu pai Agamenom. Narciso é anterior a este período de evolução da cultura grega, em que pela primeira vez se estabelecia um tribunal de júri para um julgamento, com pleno direito de defesa ao réu, como se deu no Areópago, sob a direção de Atena. Assim se compreende a severidade de seu castigo, de forma inapelável. Mesmo as variações que atribuem a Eros ou Afrodite o papel de deus vingador e justiceiro não retiram, antes reforçam, o primitivismo dessa forma de justiça.

O suicídio de Narciso acarreta um problema teórico importante e até uma aparente contradição lógica. De fato, se, por definição, em Freud, o narcisismo é o complemento libidinal do egoísmo do instinto de conservação, não estaria garantida ao narcisista uma espécie de imunidade contra o suicídio, uma vez que ele se ama acima de tudo? Por outro lado, ainda, não é a morte por suicídio uma ação flagrantemente contrária ao instinto de autopreservação? Ou, em suma, como o auto-amor pode levar à autodestruição?

Cassorla(1991), em seu estudo sobre o suicídio, pode vir em nosso auxílio, quando observa:

"Isto nos leva a um aspecto básico: o suicida não quer morrer - na verdade, ele não sabe o que é a morte. Aliás, ninguém sabe. O que ele deseja é fugir do sofrimento" (p.22).

Quer dizer, o motivo do suicídio é fundamentalmente egoísta, buscando o alívio dos tormentos, o fim de uma dor constante ou insuportável, algo, portanto, ligado a uma fantasia de libertação, profundamente radicada na libidinização do egoísmo ${ }^{17}$ ou na erotização de Tanatos $^{18}$.

Se, na origem de todo desenvolvimento psíquico, contrapusermos ao narcisismo primário o masoquismo primário - contradição que se prolonga por toda a vida do indivíduo, em fusões e defusões pulsionais, como nos oferece a visão daúltima teoria das pulsões de Freud -, diríamos que, no suicídio narcisista, o triunfo é do narcisismo sobre o masoquismo. Enquanto este

(16) http://www.grupo.org.br/logos/prof/fabio/narciso.htm.

(17) Freud, Sobre o narcisismo.

(18) Freud, Além do princípio do prazer. 
último eternizaria o sofrimento, Narciso não o suporta e põe cobro à sua vida, movido por uma fantasia de libertação, alimentada pelo princípio do prazer.

Cassorla (1985) nos oferece alguns exemplos de fantasias suicidas em que se notam fenômenos de idealização, como o encontro de uma vida plena de paz num outro mundo ou do reencontro com uma figura muito querida e idealizada na eternidade. A idealização, mostrou-nos Freud em sua obra princeps sobre o narcisismo, é um fenômeno da esfera narcisística.

A fantasia de retorno ao útero, a volta à mãe terra, pode ser teorizada como uma atração do estado de narcisismo absoluto da vida intra-uterina, seduzindo o suicida a praticar seu ato derradeiro, como que seduzido pelo canto da sereia, qual Ulisses diante de Circe, nesta trágica odisséia de regresso ao ventre materno.

\section{CONCLUSÃO}

O mito de Narciso importa em diferentes versões, as quais Canevacci, como vimos, reúne em quatro tipos, dentro dos quais aparecem diferenças em detalhes, conforme variam os registros dos autores que as contam.

A mãe é chamada Leríope ou Alcíope; o pai, geralmente o rio Cefiso, mas para Kristeva (1988), é o Zéfiro (embora pensemos que há aqui algum equívoco). Tirésias só aparece na versão ovidiana, o objeto de amor de Narciso é ele mesmo ou sua irmã e quem o toma como objeto ou é um homem, Ameínias, ou uma mulher, Eco.

O castigo de Narciso é o suicídio, o afogamento ou o definhamento e quem Ihe aplica ou é Nêmesis ou Afrodite, auxiliada por seu filho Eros (Cupido), que flecha Narciso, quando ele se debruça sobre a fonte.

A flor que nasce no local em que Narciso morre tem aparência diversa, conforme muda o narrador.

A mesma confusão impera na conceituação do termo narcisismo, já em Freud, que o introduziu, significando diferentes fenômenos, como um tipo de perversão, uma atitude psicológica, uma fase do desenvolvimento, ora colocada entre o auto-erotismo e o alo-erotismo, ora recuada aos primórdios da vida uterina, ora colocada originalmente no id, ora no ego, enquanto fonte de suprimento ou reservatório original da libido.

Cremos poder atribuir todas essas contradições e incoerências à própria dificuldade em se descrever os estágios iniciais do desenvolvimento e talvez a própria impossibilidade de atingir um perfeito conhecimento de si mesmo. Afinal, não se sabe com certeza o que se poderá enxergar ao se mirar diante de um espelho.

Evita, amigo, evita debruçar-te

Sobre o cristal de um cristalino veio,

Senão, como Narciso, irás matar-te,

Não por te veres belo, mas tão feio

(Cooper, in Bulfinch,p.127)

\section{REFERÊNCIAS BIBLIOGRÁFICAS}

AZOUBEL NETO, D. - Mito e psicanálise: estudos psicanalíticos sobre formas primitivas de pensamento, Campinas, SP: Papirus, 1993.

BION, W.R.- Os elementos da psicanálise, tradução Jayme Salomão e Paulo Dias Correa, Rio de Janeiro:Zahar Editores, 1966.

BION, W.R. - Cogitações, tradução Éster Hadassa Sandler e Paulo César Sandler, RJ:Imago Ed., 2000.

BULFINCH,T.- O livro de ouro da mitologia (a idade da fábula), histórias de deuses e heróis, tradução. David Jardim Junior, RJ:Ediouro, 1999.

CANEVACCI, M. - Quatro mitos para um Narciso "só" - Ide, SP (21) 92-101,1991.

CASSORLA, R.M.S.- O que é suicídio, São Paulo: Editora Brasiliense, Coleção Primeiros Passos:56,1985. 
CASSORLA, R.M.S.- Considerações sobre o suicídio, IN Do suicídio: estudos brasileiros, org. Roosevelt Moisés Smeke Cassorla, Campinas, SP: Papirus, 1991, p.17-26.

COTTERELL, A. - Enciclopédia de Mitologia, tradução de Margarida Vale de Gato, Central Livros Ltda., 1998

FREUD, S.(1910) - Leonardo da Vinci e uma lembrança da sua infância, Edição Standard Brasileira, vol.XI,RJ: Imago Ed.Ltda.,1970.

FREUD, S.(1914) - Sobre o Narcisismo: uma introdução, ESB, vol.XIV, tradução.Tecera de Oliveira Brito e outros,RJ: Imago Ed.Ltda., 1974.

FREUD, S.(1916/7) - Conferências introdutórias sobre psicanálise, parte III, teoria geral das neuroses, ESB, vol.XVI, tradução José Luiz Meurer, RJ: Imago Ed.Ltda., 1976.

FREUD, S.(1919) - O Estranho, ESB, vol.XVII, tradução Eudoro Augusto Macieira de Souza, RJ: Imago Ed.Ltda., 1976.

FREUD, S.(1921) - Psicologia das massas e análise do ego,ESB,v. XVIII, tradução de Christiano Monteiro Oiticica, RJ: Imago Ed.Ltda., 1976.

FREUD, S.(1923) - O ego e o id, ESB,v.XIX, tradução José Octavio de Aguiar Abreu, RJ:Imago Ed.Ltda., 1976.

FREUD, S.(1940[1938) - Esboço de psicanálise, ESB, v.XXIII, tradução José Octavio de Aguiar Abreu, RJ:Imago Ed. Ltda., 1975.

GRINBERG, L. - Culpa y depresión:estúdio psicoanalítico, $5^{\mathrm{a}}$ ed., B.Aires: Ed.Paidos, 1978.

HINSHELWOOD, .D.-Dicionário do pensamento kleiniano, tradução de José Octávio de Aguiar Abreu, Porto Alegre: Artes Médicas, 1992, p.460.

JOHNSON, R.A.- SHE, a chave do entendimento da psicologia feminina:uma interpretação baseada no mito de Eros e Psique, usando conceitos psicológicos junguianos, tradução
Maria Helena de Oliveira Tricca, SP:Mercuryo, 1987.

LACAN, J. (1949)- Écrits, Paris: Éditions du Seuil, 1966

KLEIN, M.(1946) - Notas sobre alguns mecanismos esquizóides, in Klein,M.,vol.III das Obras Completas de Melanie Klein, tradução Elias Mallet da Rocha e Liana Pinto Chaves, RJ: Imago Ed.,1991.

KRISTEVA, J(1941) -Histórias de amor, tradução Leda Tenório da Motta, RJ:Paz e Terra, 1988.

ROSENFELD, H. -Impasse e interpretação: fatores terapêuticos e antiterapêuticos no tratamento psicanalítico de pacientes neuróticos, psicóticos e fronteiriços, tradução Paulo Maria Rosas, RJ:Imago Ed., 1988.

ROUDINESCO, E, e Plon, M.- Dicionário de Psicanálise, tradução Vera Ribeiro e Lucy Magalhães, RJ: Jorge Zahar Ed., 1998.

STEPHANIDES, M.- A memória dos deuses, Hera-Afrodite, tradução Ganymedes José, Ed.Tecnoprint Ltda., coleção Mitologia Grega.

URTUBEY, L. - Sobre el narcisismo y una de sus formas de expresión: el autismo transferencial "frente al espejo", Revista Uruguaya de Psicoanalisis, 13: 149 - 186, Montevideo, 1971/2.

ZIMERMAN, D.E.- Vocabulário Contemporâneo de Psicanálise,Porto Alegre: Artmed Ed.Ltda., 2001.

\section{Documentos eletrônicos - Internet}

A fonte da vaidade, o mito de Narciso, in http:// www.geocities.com/Athens/Crete/2153/ narciso.htm - 26/01/2003.

Narciso-in http://www.geocities.com/Athens/ Olympicus/866/narciso.html-07/10/2001

Narciso-in htpp://www.grupo.org.br/logos/prof/ fabio/narciso.htm-07/10/2001. 
Narciso-in http://www.nomismatike.hpg.com.br/ Mitologia/Narciso,html-7/10/2001.

O mito de Narciso-in http://www.geocities.com/ acd-br/narciso.html-26/01/2003.

O mito de Narciso segundo Ovídio-in http:// www.psicovirtus.hpg.ig.com.br/Mito\% 20de\%Narciso.htm - 26/01/2003.
Quilici,M. O mito grego de Narciso - in http:// psipoint.com.br/ArquivoNarcisismoMito.htm 26/01/2003.

Narciso -in http://alunos.uevora.pt/ 111495/ Narcissus.html.

Recebido para publicação em 08 de abril de 2003 e aceito em 10 de setembro de 2003. 
